\title{
A Freedom beyond Conflict: The Logic of Internal Conflict and the Free Will in Maximus the Confessor
}

\author{
Basil Lourié
}

St. Petersburg, Russia

hieromonk@gmail.com

\begin{abstract}
Summary
Maximus' idea of appropriation of the divine will by deified humans, in any consistent interpretation, would mean their deprivation of their own freedom - exactly in the same manner as it could be in the case of servitude to sin. Maximus' own logic, however, was paraconsistent when applied to the case of deification (whereas not to the opposite case of the servitude to $\sin$ ). A recourse to a paraconsistent deontic logic was not a uniquely Maximian tool even in the Middle Ages and could serve as an inspiring example for logicians today.
\end{abstract}

\section{Keywords}

Maximus the Confessor - free will - deontic logic - paraconsistent logic - deification

Any social conflicts, religious or not, have roots in the internal conflicts related to human freedom, but - what is less obvious - human freedom is in conflict with logics: not with all possible logics but certainly with the logics where the law of non-contradiction is in force. Freedom requires tolerating some contradictions in reality.

* The present study is a part of a larger project Nr 16-18-10202, "History of the Logical and Philosophical Ideas in Byzantine Philosophy and Theology," implemented with a financial support of the Russian Science Foundation. 
This problem has two ends:

1. (in)compatibility between God and evil (thus, the possibility for the rational beings to choose evil),

2. (in)compatibility between the irreversibility of deification $(\theta \varepsilon \dot{\varepsilon} \omega \sigma \varsigma)$ and the freedom of the human being.

These are two sides of the unique problem. The first side was mostly discussed in the West, whereas the second side was topical in the East, especially in connexion with Christology, where the most important contributions were those of Maximus the Confessor. From both sides, the resolution of the problem could be approached only through a breach in the wall of the logic inherited from Greek antiquity, which continued to be, in Byzantium, the logic of common sense, if not simply the logic. The specific theological ideas were consid-

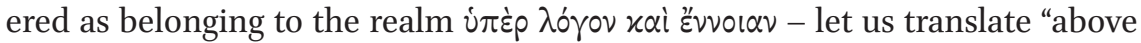
logic and reason" (Theotokion dogmatikon, tone 7$).{ }^{1}$ Nevertheless, their solutions were explained in a precise manner - theoretically, no less precise that the logical standards of Greek antiquity would have required.

Maximus the Confessor turned out to be the most successful in constructing the formal logical apparatus able to express what is beyond and above any form and any logic. For the modern, post-twentieth-century logical point of view, this could be considered, however, as a logical task, even though within a non-classical logical framework.

To appreciate the tension between Greek logic and the problems to be resolved concerning the free will problem, it would be useful to address some predecessors of Maximus, whose theological ideas were taken by him for granted.

This is the problem of the possibility - to those who dispose of free will - to choose evil. Does God tolerate the evil choice of the created free will? For the West, the problem was acute, because, if so, God would be not omnipotent. Therefore, two classical western answers to the problem of theodicy are either predestinationism (God is omnipotent, but there is no free will in the proper sense) or atheism (God must be omnipotent but there is evil, and, therefore, God does not exist). As a modern logician wrote about the Anselmian God and his recent avatars, "[a]n existent God is metaphysically impossible as the

1 This hymn is traditionally ascribed to John Damascene. 
unresolved problem of evil indicates...To be at once omniscient, omnipotent, perfectly benevolent, and the author of an actual world in which there is moral and natural evil is tantamount to being a round square".

Those in the West who took the problem of preserving free will seriously were the early seventeenth-century Spanish Jesuits, followers of Luis de Molina, especially Diego Montoya and Diego Granado, and Leibniz. ${ }^{3}$ They preferred to consider humans as inconsistent, thereby preserving God as consistent and omnipotent. According to them, God limited himself by "moral necessity" only, but God created each individual human "vague" (Leibniz's term): divine predestination establishes only "vague" concepts, which become crisp when free choice is made by free will; however, the "moral necessity" implies that God will turn the scale to the best at any outcome of the free choice.

In this way, the Jesuit Molinists and Leibniz escaped the danger that they called "semi-Pelagianism," that is, that God could be limited not by himself only but by a created will (in the case if the latter would choose evil). However, this "semi-Pelagian" attitude was the only one accepted by the Eastern fathers. Their western disciple, John Cassian, defended it against the Augustinians in the early fifth century.

In eastern patristics, the human will is free, but human reality is not "vague" in a Leibnizian sense. However, God, while omnipotent, is not consistent - to the extent that God could be compared with a round square. This idea, which is even now unbearable to the absolute majority of the analytical theologians, was explicit in Dionysius the Areopagite and was taken as it is by Maximus and the eastern fathers. In the West, however, Nicholas of Cusa criticised Albert the Great's Commentary on Dionysius for distorting his thought in this respect (the Cusanus himself followed Dionysius). ${ }^{4}$

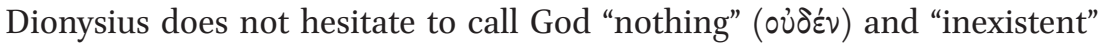
$(\mu \dot{\eta} \partial v)$ - in the sense in what the created things exist:

2 D. Jacquette, Meinongian Logic: The Semantics of Existence and Nonexistence (Perspektiven der analytischen Philosophie, 11), Berlin-New York, 1996, p. 237.

3 On this problematic area, see especially S.K. Knebel, Wille, Würfel, und Wahrscheinlichkeit. Das System der moralischen Notwendigkeit in der Jesuitenscholastik, 1550-1700 (Paradeigmata, 21), Hamburg, 2000; M. Murray, "Pre-Leibnizian Moral Necessity," The Leibniz Review 14 (2004), pp. 1-28; B. Lourié, "Philosophy of Dionysius the Areopagite: Modal Ontology," in: Logic in Orthodox-Christian Thought, ed. A. Schumann. Heusenstamm bei Frankfurt, 2013, pp. 230-257.

4 Cf. C. Steel, "Beyond the Principle of Contradiction? Proclus' 'Parmenides' and the Origin of Negative Theology," in Die Logik des Transcendentalen. Festschrift für Jan A. Aertsen zum 65. Geburtstag, ed. M. Pickavé (Miscellanea Mediaevalia, 30), Berlin, 2003, pp. 581-599. 
"[God] is the cause of the every being, and he is himself inexistent ( $\mu$ 门े oै $v$ )

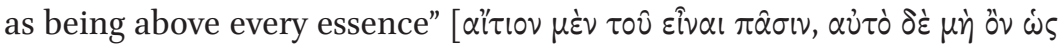

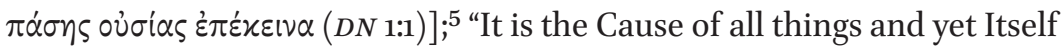

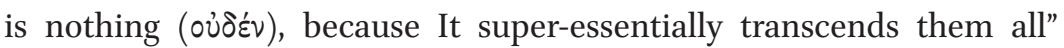

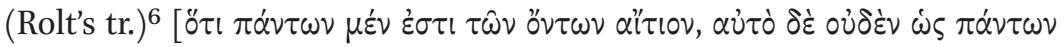

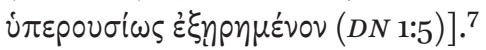

All this is extremely important to avoid the most common, among modern interpreters, errors in understanding of both Maximus' and Monothelete Christologies, as well as Maximus' teaching about free will.

How are the two natures of Christ united if they are so incomparable, to the extent that they even do not exist in the same sense of the word? The answer "within the unique hypostasis" was simply a reformulation of the question, even though useful. The standard answers in the fifth and especially the sixth centuries were formulated through the notions of "energy" and "will" ( $\theta \dot{\varepsilon} \lambda \eta \mu \alpha)$. Among the Chalcedonians, these discussions resulted in monothelete language becoming quite common, as it was among the non-Chalcedonians. ${ }^{8} \mathrm{We}$ need to skip the whole spectrum of the sixth- and seventh-century answers by focusing ourselves on the problem dealt with by Maximus. ${ }^{9}$

B.R. Suchla, Corpus Dionysiacum. I. Pseudo-Dionysius Areopagita, De divinis nominibus (Patristische Texte und Studien, 33), Berlin-New York, 1990, p. 109.16 = PG 3, 588 B.

6 C.E. Rolt, Dionysius the Areopagite: On the Divine Names and the Mystical Theology. London, 1920; electronic edition at <http://www.ccel.org/ccel/rolt/dionysius.html >.

$7 \quad$ Suchla, Corpus Dionysiacum. I, p. 117.4 = PG 3, 593 C.

8 Cf. В.М. Лурье, История византийской философии. Формативный период [В. Lourié, The History of the Byzantine Philosophy. The Formative Period], St. Petersburg, 2006, pp. 163-176, 314-316.

9 The whole topic of the human will in Christ according to Maximus has been recently readdressed by Gregory Benevich, who clarified several conundrums of Maximus's teaching. His most comprehensive work is published as Прп. Максим Исповедник. Богословско-полемические сочинения (Opuscula Theologica et polemica). Пер. с древнегреческого Д. А. Черноглазова и А.М.Шуфрина; науч. ред., предисл. и

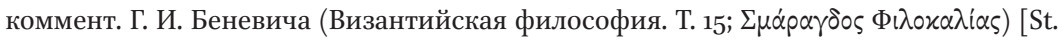
Maximus the Confessor, Theological and Polemical Writings (Opuscula Theologica et Polemica). Translation from Ancient Greek by D.A. Chernoglazov and A.M. Chouffrine; edited by G.I. Benevich; Introduction by G.I. Benevich (Byzantine Philosophy, 15; $\Sigma \mu \alpha \dot{\rho} \alpha \gamma \delta 0 \varsigma$ $\Phi(\lambda \circ \kappa \alpha \lambda(\alpha \varsigma)]$. Mt Athos-St Petersburg, 2014 [thereafter Benevich, отP], where Benevich's Introduction is, in fact, a monograph that is completed with his comments to 
His main opponents were those Monotheletes who confessed two wills in Christ. There were a number of different kinds of Monotheletism (so far nobody knows them all), with either a Monophysite or a Dyophysite background. The minimal distant from Maximus was the kind of Monotheletism - with the Dyophysite background, of course - where the human will was acknowledged in all those acts of Christ that were normally referred to by Maximus himself as epiphenomena of the human energy = natural will (such as anger, thirst or fear in the front of the death). The best known (to us) theologian of this kind is the patriarch of Constantinople Pyrrhus $(638-641,654)$ as he exposed his views in the Disputatio with Maximus in 645 .

According to Pyrrhus, the human will was appropriated by the Logos, indeed, but not after the resurrection. However, even Maximus agreed that, after the resurrection, no human passion was shown by Christ. Maximus and Pyrrhus agreed that such passions were previously accepted by the Logos accord-

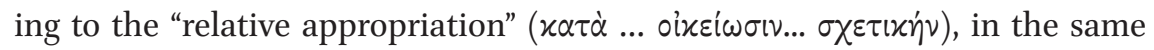
manner as we are participating in the conditions or acts of the others through

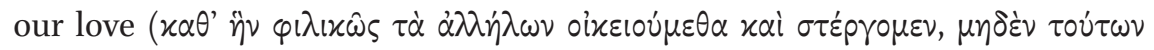

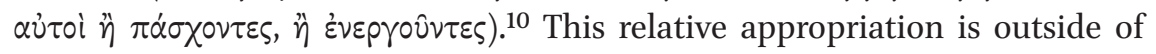
what we call incarnation. Then, Pyrrhus insisted that the human will in Christ was appropriated in this way only. Maximus disagreed answering that this would mean that the Logos was incarnated in a human nature without its natural will and, therefore, not in a really existing human nature. However, in the dispute with Pyrrhus, Maximus did not explain his positive understanding of the union between the two natural wills in the incarnation. The by contrary proof provided there was not enough.

His positive teaching is explained in his later Opuscula theologica et polemi$c a$ (esp. Nr 1). ${ }^{11}$ Here, he tried to explain what remains from the human natural will and energy if they do not express themselves as human. This problem is

the translation. Cf. my review: В. Лурье, "Максим Исповедник и его китайская логика. Мысли по поводу новых публикаций Г. И. Беневича и соавторов [В. Lourié, Maximus the Confessor and His Chinese Logic. Some Thoughts about New Publication by Gregory I. Benevich and Co-Authors]," Волшебная Гора [The Magic Mountain] 17 (2016), pp. 468478 .

The Disputatio cum Pyrrho is quoted according to an improved but still not properly critical edition by D.A. Pospelov in: Диспут с Пирром. Прп. Максим Исповедник и христологические споры VII столетия, отв. ред. Д.А. Поспелов [The Dispute with Pyrrhus. St. Maximus the Confessor and the Christological Discussions of the Seventh Century,

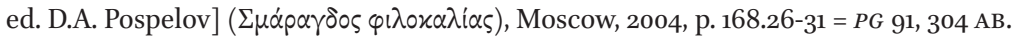
ration by Basile Markesinis. Benevich accepted its dating by Polycarp Sherwood and Jean- 
relevant for the human nature both in Christ and in the deified human person. In both cases, the human will is no longer in even the slightest disagreement with the divine one; even the prayer for "removing this cup" (Mt 26:39 // Lk 22:42) is no longer possible. Is there any liberty if there is no liberum arbitrium at all?

To my knowledge, there is no understanding of either liberty or free will in modern western culture that is compatible with this condition. Not only is there no longer any choice, but also there is no possibility of acting differentially at all.

According to Aristotle, the latter is the necessary condition of freedom of an agent: "In fact, the person act voluntarily, because in actions like this the first principle ( $\dot{\alpha} p \times \eta \dot{n})$ of moving the limbs that serve as instruments lies in him; and where the first principle lies in a person, it is in his power to act or not to act."12 The modern and mediaeval western thinkers have discussed the concept of "principle" in this definition but nobody put the definition itself under suspicion. It is obvious, however, that, according to this definition and regardless of any further understanding of the notion of "the first principle of moving," there is no human freedom in the Maximian concepts of both human incarnation of the Logos and deification of humans. For Maximus, "the moving principle" of the deified humans and incarnated Logos is only God.

If there any difference between this situation of the deified human person and the situation of a man who sold himself into servitude? Even if the origin of his action of selling himself was in himself, his further actions performed in the condition of servitude will no longer be free. Everybody including Maximus would agree with this reasoning. After all, this is nothing other than normal reasoning applied, in Byzantine anthropology, to the human condition in its sinful state. Then, should we consider the humanity in deification, in both Christ and deified humans, still preserving its free will? Why does sin deny our freedom, whereas deification does not? Why does sin suppress our natural will and put us into a condition damaging to our nature, whereas deification does not?

Claude Larchet, 645/646; cf., on the history of this Maximus's work, Benevich, отP, pp. 13-16, 185-186.

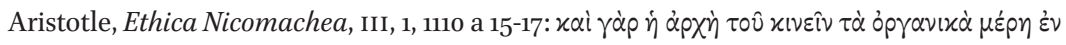

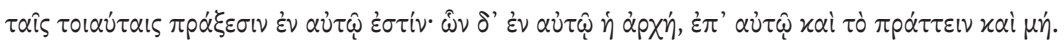
Tr. by Roger Crisp in Aristotle, Nicomachean Ethics, tr. and ed. by R. Crisp (Cambridge Texts in the History of Philosophy), Cambridge, 2000, pp. 37-38. 
In the West, a similar problem was and still is discussed in relation to God: whether God is free or not, that is, whether God was/is able to act otherwise than he acted/acts? God's freedom seems to be inconsistent with goodness if God allows evil. Leibniz resolved this problem in the way of redefinition of freedom, in submitting God's actions to the "laws of wisdom,"13 in the framework of his understanding of "moral necessity" imposed upon God. Modern philosophers do not agree with Leibniz on this point and, therefore, prefer to limit explicitly either the freedom or omnipotence of God. ${ }^{14}$ In Byzantium, as we recall, there was no need for God to be consistent. Therefore, the acute theological problem was related to the human freedom only.

\section{4}

\section{Maximus's Definition of Freedom}

To begin with, Maximus does not separate freedom from free will. Already in

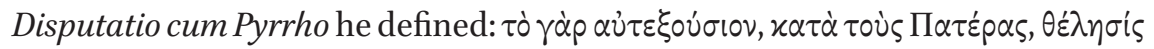
$\varepsilon \sigma \tau \iota \nu$ "the freedom, according to the Fathers, is the (natural) will." ${ }^{15}$ One often translates the word $\alpha \dot{\tau} \tau \varepsilon \xi \circ \dot{\sigma} \sigma \circ \mathrm{v}$ (or simply $\dot{\xi} \xi \circ \dot{\sigma} \sigma \circ v)$ "free will" or, even worse, liberum arbitrium, but this is not correct, even though fitting with many contexts.

In Opuscula theologica et polemica, 1, Maximus provided a detailed defini-

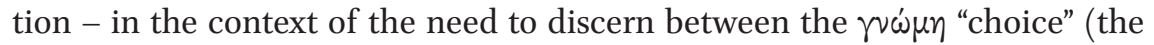

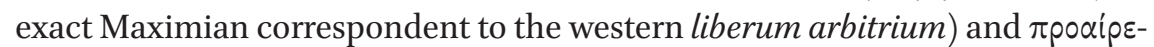
$\sigma / \varsigma$ "acting for performing a choice", on the one hand, and $\xi^{\prime} \sigma_{0} \sigma^{\prime} \alpha$ as his basic notion for "freedom," on the other: ${ }^{16}$

13 See, on Leibniz's "loix de sa [sc., de Dieu] sagesse," his Essais de Théodicée sur la bonté de Dieu, la liberté de l'homme et l'origine du mal, §§ 388, 390-391; G.W. Leibniz, Die philosophischen Schriften, hrsg. C.I. Gerhardt, Bd. 6. Berlin, 1885 [repr. Darmstadt, 1978], pp. 346347 .

14 Cf. an interesting attempt of saving "Anselmian" theism with sacrificing "the OmniGod Thesis" (that "God is omniscient, omnipotent and omnibenevolent being") by Y. Nagasawa, “A New Defence of Anselmian Theism," The Philsophical Quarterly, 58 (2008), pp. 577596; this paper is the winner of The Philosphical Quarterly Essay Prize 2007. Nagasawa proposes what he calls "The Anselmian Thesis": "God is the being than which no greater can be thought."

15 Disputatio cum Pyrrho, ed. Pospelov, p. 170.11-12 = PG 91, 304 C.

$16 \quad P G 91,17$ C-19 A. 


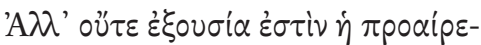

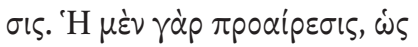

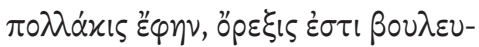
$\tau i x \dot{\eta} \tau \hat{\omega} \nu \dot{\varepsilon}^{\prime} \varphi^{\prime} \dot{\eta} \mu \hat{i} \nu \pi \rho \alpha \tau \hat{\omega} \nu \cdot \dot{\eta} \delta \dot{\varepsilon}$

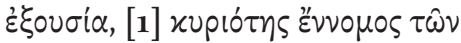

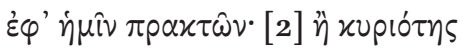
$\dot{\alpha} x \omega^{\prime} \lambda \nu \tau 0 \varsigma \tau \hat{\eta} \varsigma \tau \hat{\omega} \nu \dot{\varepsilon} \varphi^{\prime} \dot{\eta} \mu \hat{\imath} \nu$

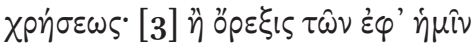

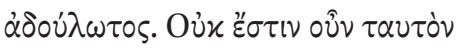

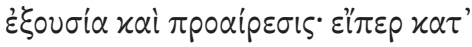

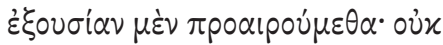

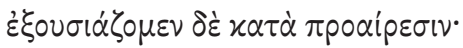

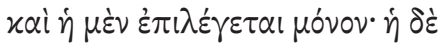

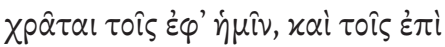

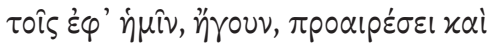

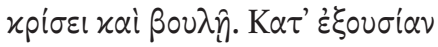

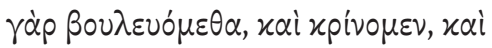

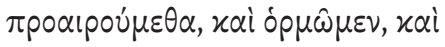

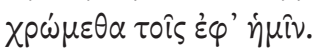

And neither the freedom is the choosing. The choosing, as I have said many times, is a wishful aspiration of what is ours to perform, whereas the freedom is [1] the innate authority to perform what is ours or [2] the unobstructed authority of using what is ours or [3] the non-slavish aspiration of what is ours. Therefore, the freedom and the choosing is not the same: if we, indeed, we aspire according to the freedom, we do not acquire the freedom according to what we aspire, and the aspiration is only choosing, whereas the freedom makes use of what is ours and what is [depending] on what is ours, that is, the aspiration, the decision, and the wish. Because it is according to the freedom that we are wishing, deciding, choosing, aspiring, and using what is ours.

Let us recall as well the definition of the (natural) will as freedom. Now we can see that freedom (and natural will) is possible where no choice is possible, whereas the contrary is not true (choice is impossible where there is no freedom). The bijection relation between choosing and freedom (free will), which is normal for the western thinkers beginning with Aristotle, is broken. Free will without free choice is proclaimed possible, as it has been recently noticed concerning Maximus. ${ }^{17}$ Let us consider this in detail.

This definition of the freedom contains three parts. The second part coincides with what is now, after Isaiah Berlin (1958), ${ }^{18}$ called the negative under-

17 Especially by I.A. McFarland, "Willing Is Not Choosing': Some Anthropological Implications of Dyothelite Christology," International Journal of Systematic Theology, 9 (2007), pp. 3-23, reprinted as ch. 4 in idem, In Adam's Fall: A Meditation on the Christian Doctrine of Original Sin (Challenges in Contemporary Theology), Chichester, 2010, pp. 88-116. Not logical but a good analysis in the framework of theological anthropology; cf. "...because what God first makes and then deifies are human beings - rational, responsible, self-conscious agents - the saint's relationship with God is a manifestation of her freedom as one who, by grace, not only knows and loves God, but does so willingly" (p. 104). ed. H. Hardy. Oxford, 2002, pp. 166-217. 
standing of freedom; this is the common denominator of almost all definitions of freedom. The third part is the Aristotelian claim of having the origin of the truly free actions in the agent himself. This condition is needed to explain, among others, why the free will of a human is necessary for God to save him. This is also an explanation why, in the incarnation, God assumed the will that would have been, at least, theoretically, slavish or non-slavish. These two aspects of the freedom were called by Nikolai Berdyaev "the freedom 'from"' and "the freedom 'for": "the freedom 'from" is the freedom of free choice between good and evil; "the freedom 'for" is the freedom of reaching one's goal. ${ }^{19}$ However, Maximus introduced something else as third and put this in first place.

The first part is at odds with the antique tradition. What means this "innate

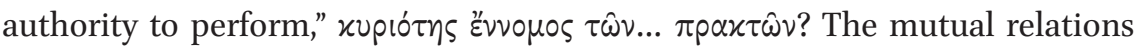
between the first and third are not obvious. To be able to perform something you need to have a "non-slavish aspiration" to perform this, whereas not vice versa. The third is a precondition for the first, but the third is senseless without the first. In this way, the two are mutually connected. Nevertheless, the first part of the tripartite definition is crucial. We can paraphrase it by saying that (true) freedom, that is, the natural free will $\left(\theta^{\dot{c}} \lambda \eta \mu \alpha\right)$, is power - some kind of.

However, in the same opusculum and elsewhere, Maximus insists that there

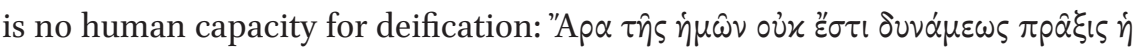

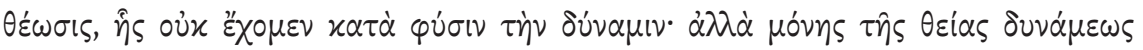
"Therefore it is not in our power to perform the deification, for which we have no power according to the nature, but only in the divine power."20 Maximus felt that this made problematic the participation of free will in salvation. Already in Amb. 7 (the text commented on by himself in the present passage) he

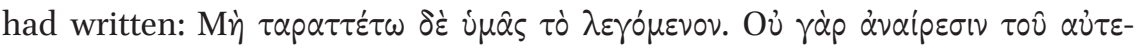

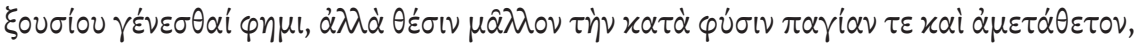

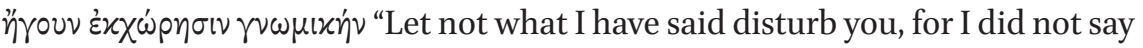
that there will be a withdrawal/deprivation of the freedom but rather (affirming) our fixed and unchangeable natural disposition, that is, a surrender of choosing." ${ }^{21}$

19 Н. Бердяев, Философия свободы [N. Berdyaev, The Philosophy of Freedom], Moscow, 1911, part II, ch. 5 (electronic edition at the site of the electronic library "Vekhi" ["Landmarks": the title of the famous volume published in 1909 by Russian religious philosophers including Berdyaev] <http://www.vehi.net/berdyaev/filos_svob/>).

$20 \quad P G 91,33 \mathrm{C}$.

$21 \quad P G$ 91, $1076 \mathrm{~B}=$ Maximos the Confessor, On Difficulties in the Church Fathers: The Ambigua. Ed. and transl. by N. Constas (Dumbarton Oaks Medieval Library), vol. 1. Cambridge, Mass.-London, 2014, pp. 88, 90 / 89, 91 (txt / Constas's tr.). 
In the present text, Maximus explains further: ${ }^{22}$

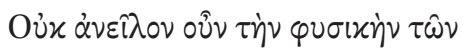

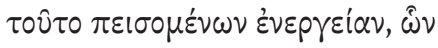

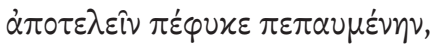

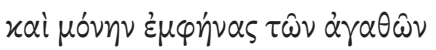
$\tau \dot{\eta} \nu \dot{\alpha} \pi \dot{\lambda} \lambda \alpha v \sigma L v \pi \dot{\alpha} \sigma \chi 0 v \sigma \alpha \nu \cdot \dot{\alpha} \lambda \dot{\alpha}$

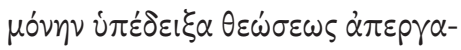

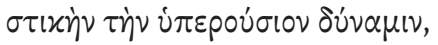
$x \tau \tau \dot{\alpha} \chi \alpha \dot{\alpha} \rho \nu \tau \hat{\omega} \nu \theta \varepsilon \omega \theta \varepsilon \dot{\varepsilon} \nu \tau \omega \nu$

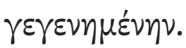

Therefore, I did not refuse those who will experience it [deification] (to have) the natural energy, - which I have represented (however) standing still from achieving its usual (goals) and subjected only to tasting the goods, - but I have pointed out as performing the deification uniquely the above-all-being power which became by grace that of those who are deified.

This is the resolution of the problem. Indeed, if the power performing the deification does not belong to the deified persons, this would mean that their freedom is destroyed. And, indeed, this power does not belong to the deified persons. However, their freedom - that must be destroyed - is not destroyed nevertheless. The power performing their deification, although without belonging to them according to the nature, becomes truly belonging to them according to the grace.

This situation is inconsistent: the same subjects do not have but have the deifying power in the same respect, namely, in the respect relevant to their freedom. "By nature" and "by grace" are certainly different as causal respects but not different as respects featuring the achieved state. This is but a particular case of the inconsistency in the very notion of the Maximian concept of deification according to the formula tantum - quantum (the deified persons become God exactly in the same extent as the Logos became human). ${ }^{23}$ Both concepts of God and of deification contain internal contradictions. In the passage of Opuscula just quoted the preceding sentence mentioned one of such fundamental contradictions: "...in the way that (God) will be both perfectly cognised and remaining completely incomprehensible" ("iv $\alpha$ xai $\tau \varepsilon \lambda \varepsilon^{i} \omega \varsigma$ s $\gamma \omega \omega \theta \hat{\eta}$,

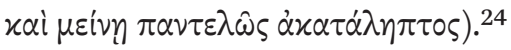

Maximus' idea that, for achieving deification, the human person needs only God himself and, therefore, must denounce any predilection, "to choose not to choose," is a basic idea of eastern asceticism. It was condemned, however, in the West, in the 1329 papal bull directed against Meister Eckhart (In agro dominico by John XXII), where it was formulated as following:

\footnotetext{
$22 \quad P G$ 91, 33 D-36 A.

23 See J.-Cl. Larchet, La divinisation de l'homme selon saint Maxime le Confesseur (Patrimoines). Paris, 1996.

$24 \quad P G 91,33 \mathrm{C}$.
} 
Octavus articulus. Qui non intendunt The eighth article. Those who seek res nec honores nec utilitarem nec nothing, neither honour nor profit devotionem internam nec sanctitatem nor inwardness nor holiness nor nec premium nec regnum celorum, sed omnibus hiis renuntiaverunt, reward nor heaven, but who have etiam quod suum est, in illis hominibus honoratur Deus. renounced all, including what is their own - in such persons is God honoured.

Meister Eckhart's doctrine aimed at was perfectly "eastern" and Maximian: that the love for God "has no why" (diu minne enhât kein warumbe; Sermon 28 ). ${ }^{25}$

\section{$5 \quad$ Toward a Logical Formalisation}

Human freedom is preserved in the way that the human acquires divine freedom. The natural human freedom implying the capacity for choosing is suppressed. However, without natural human free will it would be impossible to acquire the divine deifying power and the divine freedom.

God is hardly less free than the human being but God does not choose. The deified human being does not choose either but he/she is hardly less free than he/she was in the natural condition, not to say in the condition of servitude to $\sin$. The latter condition is simply a condition with no choice. The deified condition could not be described so simply.

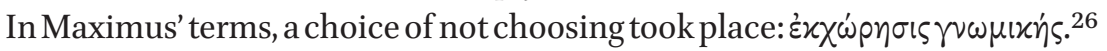
I would prefer to say that this "choice of not choosing" could be described as a choice from a unique possibility. Without using a formal language of modern deontic logics, I would provide several illustrations of such reasoning.

According to most modern deontic logicians, if there is only a unique variant to choose, there is no choice at all; this is the point of view put forward by Aristotle. ${ }^{27}$ However, it is counter-intuitive: the situation of no choice provokes panic resulting from the feeling of helplessness, whereas the situation of the choice from a unique variant, whatever hard it could be, is much more bearable, because it implies some line of behaviour.

25 Quoted according to J.M. Connolly, Living without Why: Meister Eckhart's Critique of the Medieval Concept of Will. Oxford, 2014, pp. 1-2 et passim.

26 Ambigua 7 , cited above.

27 Cf. Aristotle's Ethica Nicomachea, vI, 2, 1139 b 7, where Aristotle discussed the impossibility of the choice applied to the past events. As a generalisation of this impossibility to any case of a unique possibility, cf., e.g., J.F. Horty, Agency and Deontic Logic, Oxford, 2001, p. 16. 
Another example. Let us suppose that I am planning to choose one apple from the bowl that I see from a distance. After having approaching it, I see that there is only one apple in it. I take this apple but without feeling that I have found nothing. Were the vase void, my feelings would be different. Now, however, I feel my task of choosing accomplished, even though I had only one variant to choose. My understanding of this situation is depending, of course, on my previous decision to perform a choice. Otherwise, I would say that there is only one apple and, therefore, no choice.

The same difference - crucial in some situations - is between the glass halffull and the glass half-empty. In a similar manner (from a logical point of view), we can discern between the two kinds of limitation of human freedom, in deification and in the sinful state, as well as, by consequence, by asceticism and by the sinful passions. They are truly two different kinds of limitations, even though looking similarly, - as well as the half-full and half-empty glasses are two different glasses. 